\title{
KATEGISMUSPREDIKING (II)*
}

A C Barnard

Kategismusprediking hang onlosmaaklik saam met die Heidelbergse Kategismus. Nadat stilgestaan is by die herkoms van en bedoeling met kategismusprediking en die Heidelbergse Kategismus besien is binne die kader van ander kategismusse, is enkele van die besware teen hierdie soort prediking aangetoon. Nou kan agtereenvolgens aan die orde kom: die wese en doel van kategismusprediking, die waarde daarvan en die sinvolle inrigting daarvan in die praktyk.

\section{Die wese en doel van kategismusprediking}

Die grootste gedeelte van die saak van kategismusprediking staan of val met die vraag of die wese en doel daarvan reg gesien word.

\subsection{Kategismusprediking onderskei van kategese}

Daar is 'n verband tussen kategismusprediking en kategese, maar aan albei kan alleen reg laat geskied word indien daar duidelik tussen die twee onderskei word. Indien kategismusprediking en kategese ineen sou vloei, kan kategismusprediking nie reg verstaan en verantwoordelik beoefen word nie.

By kategese staan die onderrig en lering op die voorgrond. Dit is die weg wat die kerk gaan met die jeug van die doop tot die openbare belydenis van geloof en daarmee tot die toelating tot die nagmaal en die volle verantwoordelikheid in die gemeente. Kategese is onderrig oor die eerste beginsels, die hoofwaarhede, die hoofleerstukke van die kerk. Dit is onderrig uit die Woord.

By kategismusprediking staan die verkondiging en aanspreking op die voorgrond. Hier val die klem meer op die leer as by ander preke. Die kerkleer word egter nie in die eerste plek geleer nie, maar verkondig en wil die gemeente bring om daarvolgens te lewe. Dit is verkondiging uit en bediening van die Woord. Hier val die klem sterk op die toespitsing van die heil hier en nou, op die realisering van die heil in 'n bepaalde situasie.

Dus is kategismusprediking nie ' $n$ eenvoudige praatjie oor die dogmatiek of etiek nie, nie 'n gepopulariseerde vorm van onderrig oor die kerkleer nie, nie 'n eenvoudige verduideliking van die belydenisskrifte van die kerk nie.

Tereg het die Gereformeerde vaders dit beskou as prediking in die ware sin van die woord. Kategismusprediking moet gehandhaaf word as egte prediking, as proklamasie, aankondiging van die heil, as veelsydige woordbediening, as toegespitste aanspreking.

"Vgl. Skrif en Kerk 5/2(1984) vir die eerste aflewering. 
Waar kategismusprediking gekarakteriseer is as egte prediking, beteken dit dat hierdie prediking geen ander inhoud mag hê as die Bybel nie. Nie die kategismus of die kerkleer mag die inhoud van die prediking wees nie, maar alleen die Heilige Skrif.

As egte prediking beteken dit dat ook kategismusprediking moet wees bediening van die Woord van God. Die Bybel is die enigste basis, bron en inhoud van die prediking. Die geopenbaarde heil van God soos in die Bybel opgeteken, moet steeds aan die woord kom, moet deurgegee word, moet bedien word. Die prediking moet kom uit die Bybel en moet na die Bybel toe heenlei.

Prediking is verder uitleg, verklaring, oopvouing van hierdie Woord van God. Dit geskied na die ware aard, in sy verband en na sy ware bedoeling.

Prediking is ook verkondiging van die Woord van God. Die heel besondere boodskap van God aan die mens, soos in die Woord opgeteken, word in die prediking bekend gemaak. Dit is 'n duidelike, openbare en gevolmagtigde aankondiging. Hierdie besondere boodskap van die Bybel in die teks moet verwoord, tuisgebring word by mense in hulle konkrete lewe. Die boodskap moet gekonkretiseer word.

Prediking is ' $n$ aankondiging van ' $n$ boodskap met 'n spesifieke inhoud. Dit is die sentrale boodskap van die Skrif wat vanuit 'n bepaalde teks gekonkretiseer word. Die koninkryk van God het in die werk van Christus aangebreek. Hierdie boodskap is tot heil en redding van die mens in omvattende sin. Die heil word nie slegs aangekondig nie, maar word in die prediking gerealiseer. Die boodskap is die punt waar die werklikheid van God ons werklikheid deursny. Die verkondiging van hierdie boodskap van die veelkleurige heil roep om ' $n$ antwoord, 'n keuse teenoor Christus. Deur die prediking word ook die heil bevestig waar dit geglo word.

Dikwels word volmondig erken dat kategismusprediking alleen reg van bestaan het indien dit nie verklaring van die kategismus is nie, maar verklaring is van God se Woord. Tog word in dieselfde asem die inhoud van die betrokke Sondagafdeling só hanteer, dat die sterk uitspraak weer gerelativeer word. So verklaar K Dijk byvoorbeeld dat in die kategismusprediking "wordt aan de gemeente des Heren verklaard en geboodschapt tegelijk hoe rijk de waarheid Gods is, die in die en die bepaalde zondagsafdeling beleden wordt ..."1)

Dwarsdeur moet gehandhaaf word dat kategismusprediking steeds Skrifprediking moet wees. Die Skrif is en bly die enigste grond vir die prediking. Die boodskap van die Skrif moet hierin spreek.

\subsection{Kategismusprediking as leerprediking van die Skrif}

Die inhoud van die Bybel, die boodskap daarvan het te make met die Persoon, spreke en dade van God-drie-enig. Ons kan nie oor die Here en oor sy werk spreek sonder die leer nie. In die evangelie, in die boodskap van die Bybel, is 
daar 'n sterk element van die leer, die geformuleerde heilswaarheid. In die Bybel self, veral in die Nuwe Testamentiese briewe, speel die leer 'n baie belangrike rol. Die leer vertel wat die inhoud van die heil is en waarop dit gegrond is. Die leer is ook die weg waarlangs ' $n$ mens deel kry aan hierdie saligheid. So kan ons sê die leer het te make met die groot dade en woorde van die Here, maar is ook die belydenis van Jesus as die Christus (Mt 16:6) en die bereidheid om sy gebooie te doen (Mt 24:31-46).

In die prediking moet die leer ook duidelik spreek. Tereg sê W Trillhaas "Presies geneem is geen preek sonder leer moontlik nie ..."2) Daar is preke waar die leer 'n sterker aksent sal kry omdat dit so in die Bybel gestel word. Die prediking moet die aspek van die leer in die Bybel, duidelik na vore laat kom. Leerpreke is nie preke oor die leer buite die Skrif nie, maar preke waarin die leer van die Skrif duidelik na vore kom. Die besondere van die leerpreek is volgens Trillhaas dat "hierin die geloof vanuit die kennis en verstaan gevoed moet word ..."

Indien prediking oor die leer van die Skrif as egte prediking verstaan word dan kom kategismusprediking ook in aanmerking as egte prediking vir sover dit prediking is oor die leer van die Skrif. Alles staan en val daarmee dat die inhoud van hierdie prediking die leer van die Skrif moet wees. Die leer is dan ' $n$ wesentlike deel van die evangelie, 'n deurtrek van die evangelie na die konkrete lewe. Geloof is immers ook kennis en toe-eiening van die beloftes van God in sy Woord. By alle prediking moet die verlange leef om die gemeente op te bou in sy allerheiligste geloof ( $\mathrm{Jd}$ vs 20). Kategismusprediking wil so 'n didaktiese aksentuering van die evangelie wees.

\subsection{Die leer as hoofsaak van die evangelie}

Die leer van die kategismus wil nie 'n leerformulering los van die Bybel wees nie, maar die leer van die Bybel so na as moontlik naspreek. Wat die Bybel op verskillende plekke en op verskillende maniere leer, wil die kategismus op 'n kort en bondige wyse, oorsigtelik saamvat. So word dit inderdaad swak en feilbare mensewerk, maar dit is 'n samevatting van die leer van die Bybel, van die hoofsaak van die evangelie.

Telkens word dit van die kategismus uitgespreek dat dit die samevatting van die Woord van God, die hoofsaak van die evangelie wil wees. Die Heidelbergse Kategismus wil " ' $n$ kort en eenvoudige mondelinge berig wees van die belangrikste stukke van die Christelike leer ..."4), die hoofsom van die Christelike leer, die fundamentele stukke van die Christelike geloof. ${ }^{5)}$ Veral vir die reformatore en in besonder vir Calvyn was die leer, die doctrina, steeds die leer van die Bybel en hierdie leer is die hoofsaak van die Bybel, die evangelie. G P Hartveld wys daarop dat dit vir die reformatore gegaan het om "een doctrina-begrip dat in de verkondiging ervan heils-gebeurlijk van aard is ... Deze leer moet in ons hart worden overgeplant en in onze wandel overgaan en 20 ons in haar doen veranderen." 6 )

In die kategismusprediking kom 'n fyn onderskeiding wat steeds 
gehandhaaf moet word: die leer van die Bybel, die evangelie, mag en moet verkondig word, die geformuleerde leer van die kategismus wil so na as moontlik ooreenkom met die leer van die Bybel. In sover die leer van die Bybel ter sprake kom in die kategismusprediking, is dit geoorloof. Die leer van die kategismus mag egter nie gelykgestel word met die leer van die Bybel, die evangelie nie. Prediking van die evangelie is dieselfde as die prediking van die leer van die Bybel. Maar die leer van die Bybel soos geformuleer in die leer van die kategismus is nie dieselfde as die evangelie nie. Daarom mag die leer van die Bybel en die leer van die kerk soos in die kategismus uiteengesit, nooit gelykgestel word met die evangelie nie.

Die groot dade van God, die leer van die Bybel, word nie slegs in die kategismusprediking opgesom nie, maar ook verkondig. Dit wil ons altyd weer aanspreek en aanspoor tot medebelydenis."

\subsection{Kerkleer as belydenis}

Die leer van die Bybel word ook in die kategismus nagespreek. Dit wil steeds lewende vertolking van die evangelie in die konkrete lewe wees. In die leer word sekere standpunte ingeneem, sekere verklaringswyses bo ander gekies. Dit word toegespitse leeruitsprake wat op ' $n$ sekere verstaan van die Bybel en afsonderlike uitsprake van die Bybel, berus.

Hierdie geformuleerde leer op 'n bepaalde tydstip en wat aansluit by vorige uitsprake, word in die belydenis vasgelê. Dit word gestolde leer en belydenis. Hierdie belydenis is bedoel om steeds weer getoets en aangepas en vertolk te word. In die praktyk gebeur dit egter nie so nie. Die belydenis verkry 'n vaste en haas onveranderlike basis. Dit vang die duidelik geformuleerde geloof vas in geslote formules en wel in die gedagtewêreld van 'n bepaalde tyd van die verlede. Dit is wel die formulering van die belydenis van die waarheid wat getrek word uit die Bybel, maar dit is die geloofservaring wat op 'n bepaalde punt in die geskiedenis vasgelê word.

Die leer soos in die belydenis vasgevang, is baie belangrik. Dit is soos ' $n$ raamwerk waarbinne ons die Skrif verstaan en verkondig. Inderdaad is dit die geloofsreël, die analogia fidei, wat 'n groot hulp is by die verkondiging van die Skrif. Juis hier sal egter steeds nuwe besinning en aandag deur die kerk gegee moet word. Hierdie belydenis moet steeds weer getoets word aan die Skrif, met gebruikmaking van die beste gegewens wat deur die Bybelwetenskappe na vore gebring is. Vir elke geslag moet dit opnuut die geloofsbesit wees waarin hulle geestelik kan lewe. Waar dit geskied, sal 'n menigte probleme in verband met die kategismusprediking uitgeskakel word. Met die belydenis moet die gemeente hom heelhartig kan vereenselwig, hy moet daarmee kan lewe. In die kategismusprediking wat handel oor hierdie belydenis, sal dit die gemeente bring om dit opnuut te beaam en hom met vreugde daarin te verlustig. Die gemeente moet leer om die geloofstaal van die kerklike belydenis van die verlede te verstaan as eie belydenis. Dit veral waar hierdie belydenis as repetitio sacrae Scripturae geld. 
Die eis van Skrifprediking word verder gekonkretiseer in die eis van teksprediking.

Immers, die algemene boodskap van die Skrif word juis konkreet en vir die lewe van die mens ter sake waar dit uit 'n bepaalde teks geput word. So kom die ryke verskeidenheid van die Woord van God en die veelkleurigheid van die genade die duidelikste tot ons.

Vir elke regmatige preek word die eis gestel dat dit uit ' $n$ bepaalde preekteks gebring moet word. Juis hier word dit 'n moeilike saak. Kan die kategismuspreek nog as 'n tekspreek opgevat word? By sekere Sondagafdelings kan dit nog gaan soos waar die Tien Gebooie en die Onse Vader uitgelê word. Hier kan van die basiese preekteks uitgegaan word. Wat van die talle ander Sondagafdelings? Daar is dan ook persone wat reguit sê kategismuspreking is geen teksprediking nie en daarom nie egte prediking nie.

By elke gewone preek word 'n teks gekies en uitgelê binne die bepaalde verband of konteks. Dit is één teks wat in sy regte verband uitgelê word in die preek.

By die kategismuspreek word nie slegs 'n enkele teks of 'n enkele perikoop uitgelê en verkondig nie, maar 'n hele aantal tekste wat saam 'n eenheid vorm, wat saam een hoofsaak van die evangelie uitlê. Hier word 'n aantal tekste wat 'n eenheid vorm, uitgelê en verkondig in die bepaalde verbande waarin hulle staan. ' $n$ Aantal tekste wat almal in hulle regte verband uitgelê word, word gesamentlik as preekteks geneem en uitgelê. Hierdie preekteks uit verskillende tekste is die Skrifgrond waaruit die bepaalde Skriftema gehaal is.

Dus kan gesê word dat kategismusprediking indien dit reg hanteer word, nog steeds teksprediking kan wees. Daar mag nie slegs een van die baie aangegewe bewysplekke uit die Bybel as teks geneem word vir die prediking nie. So sal die teks geforseer word want dit kan nie die hele leerstuk dek nie. Die totaal van tekste binne hulle verband en wat deur die kerk uitgelé word, vorm die preekteks. Dit vereis ' $n$ besondere manier van omgang daarmee in die prediking. Steeds dreig die versoeking om die tekste slegs as kapstok te gebruik en dan maar die kategismus self uit te lê in die prediking. Met nadruk moet dit hier ook weer gestel word dat in die kategismusprediking nie die kategismus uitgelê word nie, maar die Skrif. Art. 68 van die Dordtse Kerkorde stel dit duidelik dat nie die kategismus uitgelê word nie, maar die hoofsom van die Christelike leer, soos in die kategismus vervat, uitgelê en verkondig word.

\subsection{Nie temapreke nie, maar preke volgens Skriftemas}

Die geliefde gebruik van sogenaamde temapreke is ' $n$ miskenning van die eis van Skrif- en teksprediking. Hier word 'n tema iewers vandaan gehaal en dit word slegs uiterlik aan ' $n$ bepaalde teks gekoppel. Die boodskap word van elders gehaal en nie uit die preekteks nie. Dit mag interessant wees, maar is nie 
Woordbediening en Woorduitleg nie. Temapreke moet ons as onskriftuurlik afwys.

Kategismusprediking word dikwels verwyt dat hy ewe-eens gebruik maak van temas en dat dit dus ook temaprediking sou wees. Indien dit waar sou wees, moet dit inderdaad nagelaat word. Hierdie verwyt word egter dikwels gemaak om die gebruik van temapreke mee te regverdig.

Waar temapreke afgewys word, word as eis gestel dat elke preek ' $n$ preektema moet hê. Dit is 'n kernagtige samevatting van die hele boodskap en waar die vrug van die teks na die situasie vandag geslaan word. Hierdie tema word egter nie van elders vandaan gehaal nie, maar is ' $n$ formulering van die boodskap van die teks. So sou elke kategismuspreek ook 'n preektema moet hê. Hierdie tema mag nie van elders vandaan gehaal word nie, maar moet uit die preekteks self kom. In die geval van kategismusprediking is dit egter, soos gesien nie slegs een teks nie, maar 'n groep tekste wat saam 'n eenheid vorm en saam die preekteks vorm. Uit hierdie preekteks moet die preektema geformuleer word. En hierdie groot tema wat as preektema geneem word, is deur die kerk self geformuleer.

Kategismusprediking is dus nie temaprediking nie, maar prediking volgens die hooftemas van die Skrif self, soos dit deur die kerk uit die aantal tekste wat saam die preekteks vorm, geformuleer is.

Hierby kom nog dat elke afsonderlike Skriftema wat uit die eenheid van die groep tekste geformuleer is, deel is van die totale boodskap van die Bybel. Die hoofskopus van die Bybel is saamgevat in die Apostolicum:

- God as Skepper, Onderhouer en Bewaarder van die mens en die hele skepping

- Die heilsdade/heilsfeite in Jesus Christus

-Die verwerkliking van die heil deur die Heilige Gees

Agter hierdie enkele Skriftemas staan die hele Bybel wat as ' $n$ eenheid die boodskap waarborg. Tereg sê R Bijlsma: "Bij het preken heeft de prediker de ganse Heilige Schrift achter zich en niet slechts de enkele tekst of pericoop, die aan die orde is. Niet het gezag van een "stukje" uit de bijbel wil zich laten gelden, maar het gezag van de sprekende God, die in de bijbel als geheel aan de woord is." ${ }^{\text {B) }}$

Vroeër is reeds daarna verwys, maar hier moet dit nadruklik gestel word dat die keuse van die aantal bewysplase wat as teks dien by die afsonderlike Sondagafdelings, en die formulering van die besondere preektemas uit die Skrif en uit die groep tekste gesamentlik, word nie oorgelaat aan die individuele prediker nie. Dit word deur die kerk self gedoen en onderskryf. Hierdie formuleringe geskied op grond van die eksegese van al die baie Skriftuurplekke en so word die hoofsaak van die evangelie uitgespel. Die lidmate onderskryf hierdie uitleg en formulering wat deur die kerk self offisieel gedoen is. Nou spreek dit vanself dat die kerk steeds weer moet toets of die eksegese wat meer as vier eeue gelede gegeld het in die lig van die enorme vooruitgang 
op hierdie gebied nog so gehandhaaf kan word, of ander tekste nie ook ter sprake gebring moet word nie. Die kerk wat lewe en wat sy leer belewe in die konkrete werklikheid en wat die Bybel lief het, sal steeds die kategismus opnuut moet interpreteer met die oog op die verantwoordelike bediening van die Woord.

Toe die kategismus opgestel is, is getrag om dit so naby as moontlik by die Skrif te hou. In die verband merk H H Barger op: "Niet genoeg kunnen wij het Bijbelsche karakter van dit boek roemen." ${ }^{\prime \prime}$ ) Th L Haitjema voeg hierby: "De bewoording van den Heidelbergse Katechismus zijn over het algemeen zóó dicht bij de Heilige Schrift gebleven, dat het voor een dienaar des Woords ... de volle diepe accoorden der Woord-verkondiging gaan klinken."101

\section{Die voordele en waarde van kategismusprediking}

Kategismusprediking is nie slegs regverdigbaar as egte prediking nie, dit het ook vir die kerk en vir die prediking groot voordele. Dit is nie genoeg om slegs die nadele van of besware teen kategismusprediking te weerlê nie, die werklike waarde daarvan en die winsoogmerke daarmee moet duidelik uitgespel word.

\subsection{Opbou van die gemeente}

Omdat die kategismus die hoofsaak van die evangelie bevat en die vier basiese kategetiese leerstukke van die gebod, die gebed, die geloof en die sakramente sistematies uitlê, beteken die prediking aan die hand van die kategismus dat die gemeente opgebou word in sy geloof. Dit gaan nie slegs om die dinge wat mense graag wil hoor nie, maar wat hulle nodig het vir hulle lewe en werk in die wêreld. Tereg skryf K Dijk in hierdie verband: “... om de gemeente in te leiden, telkens weer, in de schatten der waarheid; om haar te laten zien, (vooral in deze tijd) de rijkdom van haar belijdenis; om haar de diepe zin van de christelijke leer te doen verstaan; om haar te bepalen bij de baat van wat zij gelooft, en haar enige troos in leven en sterven."11) Kategismusprediking is noodsaaklik om die gemeente steeds weer bewus te maak van sy geloofsbasis en hoe dit vandag na die praktyk van die lewe deurgetrek moet word. Die prediking mag dus nie by die teorie, die leer bly steek nie, maar moet "hande" en "voete" in die praktyk kry.

\subsection{Vermeerdering van geloofskennis}

Die geloofslewe het ook 'n kenniselement. Sonder hierdie basiese kennis verval die gemeente in onkunde en sweef sy geloof in die lug. Juis deur die kategismusprediking word die kennis van die waarheid en geloof soos in die Skrif vervat, vermeerder. Hier gaan dit om die Waarheid van God, om die kern van die evangelie, om die Christelike leer, om die behydenis van die kerk. Kategismusprediking staan ten dienste van die ontsluiting van die heilsgeheime van God se omvattende waarheid vir die mens van vandag. 
Waar die kategismus die weg van saligheid duidelik aantoon, beteken dit dat die prediking oor die kategismus help dat die hele spektrum van die heil en die geloof ter sprake kom.

\subsection{Noodsaaklik vir onderskeiding van waarheid en dwaling}

Die gelowige leef in 'n wêreld waar sy geloof weerspreek word, waar die Woord van God tersyde gestel en verwerp word. Daar is 'n magtige stroom van dwaling, afwykings van die gesonde leer en ketterye. Op baie maniere word hy aangeveg deur die wêreld, deur die duiwel en deur sy eie vlees. Die waarheid word op baie maniere verdraai en die leuen word as die waarheid gestel.

In hierdie lewe is die kategismusprediking 'n magtige hulp om te onderskei tussen waarheid en dwaling, om die dwaling en leuen te onderken en te bestry, om positief vir die waarheid en die gesonde leer te stry. Die kategismus wys allerlei verkeerde standpunte uit. Daar sal egter ook moet gekyk word na nuwe dwalinge en vreemde praktyke vandag.

\subsection{Troos en versterking}

Kategismusprediking wil bring tot die ware kennis van die genade en die saligheid en die vertroue dat mense die redding van Christus inderdaad deelagtig geword het. Die geloof word op soveel maniere aangeveg. Baie duidelik stel die kategismus daarteen die ware "troos" van die evangelie. Die boodskap van die volle raad van God gee aan die gemeente die sekerheid dat hy by die kern van die evangelie uitgekom het. Hy word opgeroep om vas te hou aan sy geestelike erfenis.

Kategismusprediking help ons om 'n duidelike beeld te kry van ons geestelike "Gepäck" en ons teologiese kennis. Dit voorsien ons van die "reisproviand". 12)

\subsection{Hulp vir die prediker}

Nie net vir die gemeente nie, maar ook vir die prediker is die reëling van kategismusprediking 'n geweldige hulp. Daardeur word hy verplig om die hele raad van God tot voordeel van die gemeente in die prediking aan die orde te stel. Hy hoef nie na preekstof te soek nie, want dit word reeds op 'n ordelike en sistematiese wyse aan hom gebied.

Kategismusprediking help ook die prediker om te bly by die hoofsaak van die evangelie, om te bly binne die raamwerk van die leer en belydenis van die kerk, en om selfs deur sy prediking geestelik te groei.

Die inhoud van die leer kom nie slegs ter sprake in die kategismuspreke nie, maar ook in ander preke.

\subsection{Toerusting en inoefening}

Kategismusprediking het ook die voordeel dat dit die geleentheid bied om nie 
slegs op bevatlike en oorsigtelike wyse kennis te verkry van die hoofsaak van die geloof nie, maar ook dat die gemeente hierdie kennis prakties in hulle lewens kan toepas. Kategismusprediking is by uitstek die geleentheid waar die gemeente die toerusting moet kry hoe hulle geloofkennis gebring kan word tot lewenskennis. Hulle kan die toerusting bekom wat nodig is om as lewende, kundige en toegewyde gelowiges in die konkrete wêreld te leef en te werk. Deur bespreking, deur die stel van vrae, deur die geloofsake deur te praat, verkry hulle die nodige toerusting.

By die toerusting kom ook die inoefening. Wat geleer word, word self vertolk, verwerk, geïnterpreteer, geleer om dit uit te dra na andere en om dit te verdedig. Juis omdat dit handel oor die wesensake van die geloof, kan die inoefening plaasvind om hierdie wesensake inderdaad te kan beleef, te kan toepas en daaruit te leef.

\section{Die sinvolle inrigting van kategismusprediking}

Nou kom ons by die belangrikste en die sinvolste van kategismusprediking, maar wat tegelyk die moeilikste deel is - naamlik die sinvolle en effektiewe inrigting daarvan. Hier word baie kategismuspreke gemaak of gebreek. Hier triomfeer of struikel die hele saak van die prediking. Hier word belangstelling gewek en liefde gekweek vir die kategismuspreek, of groei die verveling en die weerstand.

\subsection{Die Skrifbasis steeds vashou}

Dwarsdeur die kategismuspreek moet onmiskenbaar duidelik word dat die preek nie kom uit die kategismus nie, maar uit die Bybel self; dit is nie uitleg van die kategismus nie, maar van die Skrif. Die aanbieding en inkleding van die kategismuspreek moet sodanig wees dat almal besef ons het hier te make met Woordbediening.

Reeds in die aankondiging en inleiding van die kategismuspreek, moet baie duidelik word dat dit nou nie om die kerkleer gaan nie, maar om die Bybel, om die evangelie. So kan byvoorbeeld aangekondig word dat die preek kom uit verskeie tekste, en dat dus die Skrif self volgens 'n bepaaide Skriftema hier aan die woord is. Hier volg bediening van die Woord, soos dit in die kategismus saamgevat is.

In die preek mag die letterlike bewoording van die kategismus nie so op die voorgrond staan dat die Woord van God wat daarin bely word op die agtergrond te staan kom nie. Deur die kategismuspreek moet die woord van A Kuyper ter harte gehou word: "Elke afdeeling belijdt immers een waarheid, die God in Zijn Woord heeft geopenbaard en die wordt in de catechismusprediking verkondigd ..."13) W D Jonker beklemtoon dat in die prediking self die konkrete tekste ter sprake gebring moet word. Die saak wat in die kategismus aan die orde is, moet werklik in die Skrif as ' $n$ eksistensiële waarheid ontdek word. Die Skrif moet die kategismusprediking van begin tot einde beheers. ${ }^{14}$ 


\subsection{Die saak van die preekteks}

Hierbo is dit reeds vasgestel dat soos alle egte prediking, kategismusprediking ook teksprediking moet wees. Dit moet uitgaan van 'n preekteks. Hier is dit egter nie slegs een teks in 'n bepaalde verband nie, maar 'n hele aantal tekste saam wat in verskillende kontekste vanuit een sentrale Skriftema gebruik word as preekteks.

Die groot vraag is nou hoe dit in die praktyk van die prediking oor die kategismus hanteer moet 'vord. Hier is en word vanuit 'n hele reeks benaderings gewerk:

* Slegs een van die hele aantal tekste wat as bewys by die betrokke Sondagafdeling aangegee word, word gelees en uitgelê. Dit kan ook weer na een van twee kante toe uitval:

- die een teks kan as preekteks gebruik word en die hele Sondagafdeling word daaruit verklaar. Dit beteken dat die teks geforseer word om as grond van die hele afdeling te dien. So iets is egter nie Woordbediening nie. Indien ' $n$ hele aantal tekste saam die fundering van ' $n$ afdeling is en net een daarvan word uitgelê, beteken dit verder dat dit noodgedwonge skeefgetrek word.

- daar word wel 'n teks gelees en as grond vir die afdeling aangegee, maar dit is slegs 'n vlag wat nie die lading van die skip dek nie. In die praktyk is die teks net ' $n$ kapstok vir die preek en word in werklikheid die kategismus verklaar.

Hierdie weg na sy twee moontlikhede kan ons nie opgaan nie.

* Daar word sonder meer uitgegaan van die kategismus sonder 'n bepaalde teks, omdat gesê word die kategismus steun tog op 'n aantal tekste. Wel sal beleefdelik ' $n$ teksgedeelte gelees word.

Al skyn dit die maklikste weg te wees en al het die Voetiane daarvan uitgegaan dat die wesenlike inhoud van die Bybel in die kategismus ingegaan het sodat wie volgens hulle die kategismusantwoorde uitlê, ook die inhoud van die Bybel binnedring, ${ }^{15}$ ) mag ons ook nie hierdie weg opgaan nie. Wie dit sou doen, het die Skriftuurlikheid van die kategismusprediking prysgegee.

* Al die tekste by ' $n$ bepaalde afdeling word eers voorgelees en dan volg die preek volgens die kategismus. Hierdie benadering het ' $n$ geringe voorsprong bo die vorige hierbo. Die gemeente hoor ten minste uit die Bybel die verskillende Bybeltekste waarop die afdeling steun. Dan word die tekste egter gelaat by die lees daarvan en die kategismus word as ' $n$ tweede of die eintlike bron vir die prediking gebruik. Die prediking geskied nie uit die betrokke tekste wat as preekteks moet geld nie. In werklikheid is die voorlees van die aantal tekste net 'n mooi vertoon.

Hierdie benadering word nog steeds deur die wesentlike beswaar gedruk, naamlik dat so 'n kategismuspreek geen teksprediking is nie. 
* Die teksuitleg en kategismusuitleg word van mekaar geskei. Omdat een teks nie alles dek nie en al die tekste nie saam uitgelê kan word in die preek nie, stel $\mathrm{L}$ A Pretorius voor om teksuitleg en kategismusuitleg van mekaar te skei in die preek. Vir hom beteken dit dan "dat die kategismus nie gepreek sal word na aanleiding van ' $n$ bepaalde teks uit die Skrif nie ... Daarom, omdat 'n Sondagsafdeling op verskeie gedeeltes uit die Bybel gegrond is, sal teksprediking nie reg laat geskied aan talle ander gedeeltes uit die Heilige Skrif nie." Dus kom dit daarop neer dat ook maar weer die kategismus op sy eie uitgelê word. ${ }^{161}$

* Al die tekste van 'n afdeling word gelees en in die preek verklaar. So sou ons seker die beste reg laat geskied aan die beginsel van die Skrifmatigheid en teksmatigheid van die kategismusprediking. Die groot probleem is dat dit ' $n$ enorme taak is om alles in die bestek van 'n preek in die erediens te behandel. Vir A Kuyper is dit die mees aanvaarbare weg in die kategismusprediking. Hy skryf: "Daarom zagen onze vaderen terecht in, dat de stelselmatige prediking van de hoofdstukken onzer belijdenis slechts dan mogelijk was, als men niet één tekst, maar tien, twaalf teksten tegelijk nam en uit die alle saam de waarheid putte. Vandaar dat de catechismus prediking hun niet was: nietprediking van de Schrift, maar een predikatie over alle die teksten, die uiteindelijk onder elke vraag vermeld stonden. Die aanhaling van teksten onder den catechismus is dus geen bijzaak, maar hoofdzaak. Het is niet: zó denkt de Heilige Schrift er ook over!, maar: uit die en die goudaderen van de Schrift is dit goud opgedolven." 17 "

* Prediking oor die preekteks van al die verskillende tekste. Ons moet die gedagte vashou dat prediking die uitleg is van die preekteks. Daarom gaan dit nie om óf die uitleg van die een afsonderlike teks of die uitleg van die verskillende los tekste van die afdeling nie, maar om die één preekteks wat saamgestel is uit al die verskillende tekste waarop die Skriftema rus. In die voorbereiding op die kategismusprediking, moet die preekteks en wat uit 'n hele aantal tekste bestaan, gelees en deeglik uitgelê word. Voor die preek word ook die verskillende tekste gelees, maar veral die een of twee Bybelgedeeltes waarin die tekste voorkom en wat dien as die sterkste begronding van die inhoud van die Skriftema die betrokke Sondagsafdeling. In die preek word nou die preekteks uitgelê vanuit sy sentrale bedoeling soos die eksegese uitgewys het. Hierdie uitleg sal uit die aard van die saak grootliks ooreenkom met die geformuleerde tema van die Sondagsafdeling. Die boodskap soos wat dit uit die preekteks kom en wat die essensie van die Sondagsafdeling sal uitspreek, word dan met krag verkondig, gekonkretiseer. So word nie uit die belydenis gepreek nie, maar oor die Woord van God wat die belydenis dra. Dit gee aan prediking sy fundering en gesag. Die Skrif word primêr uitgelê, nie die belydenis nie. "Een catechismuszondag is geen tekst en behoeft allereerst de nauwkeurige exegese niet, die voor het verstaan van ieder Schriftgedeelte onmisbaar is ..."18) 
Hierdie benadering laat die beste reg geskied aan die teksmatigheid en Skrifmatigheid van kategismuspreek. Tegelyk wys dit dat daar hard gewerk moet word om só uit die kategismus te preek.

\subsection{Aktueel en konkreet}

Juis omdat kategismusprediking die Bybel vanuit die geformuleerde leer ter sprake bring, word dit steeds bedreig deur die gevare van dogmaties, abstrak, teoreties, verstandelik en lewensvreemd te wees. Om hierdie gevare te oorwin, moet die klem lê op:

* Die Skrif moet steeds vanuit die konkrete preekteks aan die woord kom. Omdat die Bybel steeds konkreet is en vanuit verskillende konkrete lewenshoeke oor God, oor die mens en oor die geloof spreek, daarom moet die Bybel self aan die woord gestel word. Hierin moet die konkrete boodskap, die egte bedoeling van God daarmee, die lewende spreke van God, die viva vox evangelii, duidelik weerklink. Die kategismus het bedoel om konkreet oor die groot geloofswaarhede van die Bybel te spreek. Hierdie lyn moet skerper deurgetrek word. Daarom moet die vertrekpunt van die preek steeds vanuit die Bybel, vanuit die Woord van God, en daarom vanuit die bedoeling van God, ja, uit sy hart ontspring. Hier is die onuitputlike bron van lewe en krag, en waar die preek uit hierdie bron vloei, kan dit nooit teoreties en abstrak wees nie.

* Om aktueel en konkreet te wees, moet ook aandag gegee word aan die gemeente, die mens in sy situasie, die mens in sy konkrete lewe en stryd van elke dag. Dit is die ander kant van die brug van die preek, die raakvlak by, onder en in die mense. Die hoofsaak van die evangelie soos in die leer uitgedruk, moet steeds die lewende evangelie bly. Die woorde van God, die antwoord van God, sy krag, genesing en bystand moet heel direk en persoonlik ervaar word. Die leer moet weer geloofsbelydenis en geloofservaring vir die mense word. "Dit is beslissend om die "leer" in die "lewe" te verander of terug te verander ..."19)

Dus hoe beter die prediker die boodskap van God in die preekteks kan opvang en hoe nader hy by die mense staan en hulle werklik in hulle behoeftes ken, hoe meer effektief sal die boodskap oorkom, hoe meer sal die preek aktueel en konkreet wees.

* Juis by kategismusprediking mag nooit ' $n$ lewensvreemde of verouderde stof gebied word nie. In die wyse van aanbieding van die leerstof van die Heidelbergse Kategismus wou die opstellers dit graag nuut hou. So praat Oorthuys selfs van die "ewige jeugd van Heidelberg" en Haitjema onderstreep dit: "... de nooit verouderende, dus altijd actueel blijvende, inhoud van de christelijke geloofswaarheid" van die Heidelbergse Kategismus. ${ }^{20 \prime}$ Om aan hierdie mooi sieninge getrou te bly, sal die Skrif egter steeds nuut in die kategismus moet spreek en dit sal steeds nuut vertolk en deurvors moet word. 
Die prediking sal dit in die praktyk van die mense moet laat spreek. Dit kan en moet steeds boeiend en interessant wees. Daarvoor is harde werk baie nodig. Die wagwoord bly steeds: deeglike eksegese, deeglike agtergrondstudie van die Bybel, deeglike kennis van die mens en sy node en die kennis van die beste homiletiese en kommunikatiewe beginsels.

\subsection{Behoorlike strukturering}

Soos by elke ander vorm van prediking, moet ook die kategismuspreek behoorlik geformuleer en gestruktureer wees. Dit is ' $n$ groot dwaling om te meen ons kan volstaan met die inhoud sonder die vorm, net so min as wat ons kan werk met ' $n$ vorm sonder inhoud. Die twee hang onafskeidbaar saam. Die vorm verkry sy krag en betekenis van die inhoud wat hy dra, en die inhoud word effektief en kom tuis in die lewens en harte van mense deur die regte vorm of struktuur. Die inhoud is die primêre, maar die vorm is die kleed, die houer, die draer, die begeleier van die boodskap. 'n Goeie inhoud is onmisbaar. Net so is 'n goeie struktuur onmisbaar, want dit verleen aan die boodskap sy trefkrag, word sy stem, sy hande en voete.

Mense luister graag na 'n preek wat sorgvuldig voorberei, goed gestruktureer is en effektief aangebied word. Hulle luister graag na dit wat hulle in die hart tref, en dit gebeur waar die boodskap die pad na die hart volg.

'n Preek is ' $n$ rede. Dit geld ook van die kategismuspreek. ' $n$ Rede spreek tot mense. Daarom moet dit kom in die vorm van die spreektaal. Hoewel dit geskryf word, moet dit geskied in die spreektaal en nie in skryftaal nie.

Elke kategismuspreek moet 'n preektema hê wat in 'n kernagtige sin die hele preek saamvat. Hierdie preektema moet deur die geskikste struktuur ont vou word. Die teks en preektema bepaal ook die beste struktuur en verdelings.

\subsection{Gesonde variasie}

Om nuut en vars te wees, mag die kategismuspreek nie maar altyd op dieselfde wyse geskied nie. Die stof bly basies dieselfde as die kategismus herhaal word, maar dit moet sprankelend nuut aangebied word. Ou, bekende dinge gaan aan mense verby. Hulle sluit hulle maklik af daarvoor. Om mense daartoe te bring om opnuut aandag daaraan te gee, moet dit anders en nuut aangebied word. ' $n$ Mededeling is eers dan werklik informasie as dit nuut en verrassend, onverwags en nie vanselfsprekend is nie.

'n Belangrike manier om die bekende stof van die kategismus nuut te stel, is deur variasie. Telkens word die kategismus vanuit verskillende gesigspunte beskou. ${ }^{21)}$ E G van Teylingen skryf tereg: "So is dit ongetwyfeld reg dat die uitleg van die kategismus in die preek steeds weer na die begin moet terugkeer. Dit is egter nie bloot tot herhaling nie, maar om ' $n$ nuwe begin te maak, nuwe Bybelse aksente te lê, om die leer in die tyd en lewe in te dra en dit opnuut weer met die historiese plek van mens en wêreld te konfronteer."221 
Die variasie moet nie gesoek word deur slegs een vraag op 'n keer te behandel nie. So iets moet die uitsondering wees. Die Sondagafdeling behandel ' $n$ belangrike tema van die geloof. Waar nou slegs een vraag geneem word, kan die hele tema skeefgetrek word.

\section{$5.6 \quad$ Leer en leermetodes}

Kategismusprediking is Woordbediening waar die aksent veral op die leer val. Hier sal die aksent duideliker op die onderwysende val, op die bekendstelling van die evangelie soos saamgevat in die leeruitsprake en op die verdediging van die leer.

Leer beteken geensins dat dit slegs verstandelik sal wees nie. Dit gaan om die mens in die diepste van sy bestaan te raak en te verander. Om werklik te ken en te verstaan, beteken om daardeur verander, in beweging gebring te word. A Exeler onderstreep hierdie gedagte: "As my geloof ... bevrydend, helend en opeisend moet uitwerk, dan moet dit in die persoonlike woord kom: in die Woord voor God en in die woord van die mense onder mekaar." ${ }^{23}$ ) Hierby geld: "Sonder hierdie dieptestempeling, sluit die mens homself in die rasionele af van die veranderende krag van die boodskap". ${ }^{24)}$

Veral by die leerprediking kan die moderne hulpmiddels en leermiddels met vrug gebruik word. Daar behoort gereeld na die preek geleentheid gegee te word vir vrae en bespreking. So alleen kan die prediker goed vasstel of die boodskap tuisgekom het en hoe dit tuisgekom het. Mense hoor dikwels iets anders as wat die prediker sê. Daar kan ook gebruik gemaak word van aanskouingsmateriaal. Met oorleg en diensbaar aan die prediking, kan ook die oorhoofse projektor en ander tegniese apparaat gebruik word.

\subsection{Frekwensie van kategismusprediking}

Vir twee uiterstes moet gewaarsku word: vir te min preke oor die kategismus, want ook hier geld: onbekend mak onbemind; en ook vir te veel kategismuspreke, want so kan daar 'n moegheid en oorversadiging intree.

Die omstandighede sal 'n sterk woord meespreek. Indien in 'n kerk of gemeente 'n groot onkunde sou heers oor die kerkleer en die kerk en gemeente bedreig sou word deur allerlei sektes en dwalings, sal kategismusprediking baie noodsaaklik wees.

Dit is te betwyfel of ' $n$ voorskrif van die kategismus vir elke Sondag gewens is. Waar daar ernstige nood is, sou ' $n$ gebruik van die kategismusprediking elke tweede Sondag baie goed wees. 'n Kategismuspreek elke tweede of derde Sondag lyk ' $n$ baie goeie frekwensie.

In elke geval moet die kategismus in volgorde gepreek word en nie willekeurig nie. Waar die aangewese orde prysgegee word, word die gemeente nie gebou nie, maar juis verwar. Immers, die kategismus behandel die weg van saligheid en waar die orde versteur word, word die weg onseker gestel. 


\subsection{Geloofstaal opnuut bely}

Die belydenis wat eens in die harte van mense gelewe het en wat sy neerslag gevind het in die kategismus, moet weer vir die mense vandag nuut word, ook vir hulle moet dit belydenis van húlle harte wees. Die belydenis van die vaders moet ons beaam. Die geloofstaal van die vaders moet ook óns geloofstaal word. Die hoofsaak van die evangelie moet vir ons die hoofsaak vir ons leer en lewe wees.

Die leer moet uit die hart tot die hart kom. Dit loop langs die weg van persoonlike kontak, persoonlike verhoudings en persoonlike belewing. Om met Adolf Exeler te spreek: "Om die geloof te leer is buitengewoon belangrik, maar mens leer geloof nie primêr uit sisteme van sinne nie. Die weg tot 'n lewende geloof lei veral oor die persoonlike verhoudings tot gelowige mense, en oor 'n persoonlike verhouding tot Jesus Christus, wat betrokke maak, wat die lewe kennelik beïnvloed en wat aan die mens ervaarbaar goeddoen." 25 )

\section{9 'n Geseënde gebruik}

Om die mense te bereik, moet die kategismus werklik God se Woord aan die woord laat kom. "Die mees geslaagde kategismuspreek kom tot stand, wanneer die predikant die sentrale punt waarom dit in 'n afdeling van die kategismus gaan, in 'n bepaalde perikoop of Skrifgedeelte so duidelik uitgespreek vind, dat sy verkondiging feitlik heeltemal in die uitleg van daardie Skrifgedeelte kan opgaan."26) Hierby moet ook kom dat hierdie boodskap met oortuiging uitgespreek word op so 'n duidelike en direkte en konkrete wyse dat dit inderdaad die konkrete hoorders in die kern van hulle bestaan aanspreek. Die diepste geheim van alle prediking en dus ook van kategismusprediking, is die werking van die Heilige Gees. Die Gees werk waar die Woord gehonoreer word, waar in die Here geglo word, waar die hulp, leiding en verligting van die Gees afgebid word.

Die kategismus kan verkeerd hanteer word in die prediking. Om dit werklik te laat slaag, vereis harde werk en gebed. Dit bly egter steeds noodsaaklik. Ook dit moet gebruik word tot vermeerdering van die kennis van die gemeente, tot die opbou van hulle allerheiligste geloof, tot die toerusting tot beter getuienis en diens, maar bo alles tot die groter eer van God.

\section{NOTAS}

1. K. Dijk, De Catechismus in haar verscheidenheid, Franeker s.j., 6.

2. Evangelische Predigtlehre, München ${ }^{3} 1948,110$.

3. A.w., 110.

4. H. Graffmann, Erklärung des Heidelberger Katechismus, Predigt und Unterricht des 16. bis 18. Jahrhunderts, in: Handbuch zum Heidelberger Katechismus, Hrs L. Coenen, Neukirchen-Vluyn 1963, 63.

5. Th. L. Haitjema, De prediking als catechismus-prediking, in: Handboek voor de prediking Deel II, Amsterdam, 1948, 294.

6. "Prediking en catechese", Homiletica en Biblica, 22/9(1966), 194. 
7. E.G. van Teylingen, Der Katechismus in der Predigt, in Handbuch zum Heidelberger Katechismus, 194

8. R. Bijlsma, De Preek, Kampen 1977, 46.

9. Ons Kerkboek, Rotterdam ${ }^{2} 1907,1975$.

10. A.W. 298.

11. K. Dijk, "Hoe maak ik mijn preek", Homiletica en Biblica, 22/2(1963), 35v.

12. A. Péry, Der Heidelberger Katechismus, Neukirchen s.j., 6.

13. De Heraut, 18 Maart 1888, aangehaal deur F. Guillaume, De catechismus in den dienst des Woords, (Red. R Schippers), Goes 1944, 173.

14. Die Woord as opdrag. Pretoria 1976, 133.

15. Vgl. J.F.G. Goeters, Entstehung und Frühgeschichte des Katechismus, in: Handbuch zum Heidelberger Katechismus, 73.

16. L.A. Pretorius, "Die Heidelbergse Kategismus", Hervormde Teologiese Studies, Jaargang 23/4.

17. A.W., 172

18. F. Guillaume, a.w., 173.

19. L. Fendt, Homiletik, 1970, 67.

20. Th. L. Haitjema, De Heidelbergsche Catechismus, Wageningen 1962, 11.

21. Vgl. praktiese voorstelle by K Dijk, De catechismus in haar verscheidenheid, 194.

22. Der Katechismus in der Predigt, 194.

23. Die Sorge um einen dialogfähigen Glauben, in: Gemeindekatechese, Freiburg 1981, 25

24. W. Massa, Predigttypologie, in: Handbuch der Verkündigung, Bd II, Freiburg 1970, 267.

25. A.W., 28.

26. W.D. Jonker, a.w., 133.

\section{ADDISIONELE LITERATUUR}

Aalders, C., e.a., Altijd Zondag, Deel I, Nijkerk 1948.

Adam, G., Der Unterricht der Kirche, Göttingen 1980

Augustinus, A., Het eerste geloofsonderricht, Baarn, Amboboeken 1982.

Barnard, A.C., Die erediens, Pretoria 1981.

Barth, K., Einführung in den Heidelberger Katechismus, Zürich 1960.

Bäumler, C., Luther, H., Konfirmandenunterricht und Konfirmation, München 1982.

Biemer, G., Firmung, Würzburg 1973.

Biesterveld, P., Het Gereformeerde kerkboek, Uitg. Het Traktaatgenootschap "Filippus", 1903.

Bijlsma, R., Kleine Catechetiek, Nijkerk 1962.

Bizer, C.. Unterricht und Predigt, Gütersloh 1972.

Boersma T., e.a., De hoofdsom van het evangelie, Enschede 1970.

Calvin, J., Der Genfer Katechismus von 1537, Gütersloh 1978.

De Graaf, W., De herkomst van onze belijdenisschriften, Utrecht s.j.

De Klerk, J.J., Prediking, Pretoria 1977.

De Villiers, D.W., Riglyne vir die kategese volgens die sinode van Dordrecht, NGTT 2 (1970).

Dienst, K., Die lehrbare Religion, Gütersloh 1976.

Dijk, K., De dienst der prediking, Kampen 1955.

Dijk, K., Catechismusprediking, in: Christelijke Encyclopedie II, Kampen 1957.

Engelbrecht, B.J., Kategismusprediking. in: Almanak van die Ned. Herv. Kerk, 1960.

Frör, K., Hrsg., Confirmatio, München 1959.

Haerst, L., u.ä., Der katechetische Dienst, München 1980.

Hartvelt, G.P., Alles in Hem, Aalten 1966.

Heintel, E., Sehen und Tun in der Biblischen Unterweisung, Kassel 1965.

Hengel, M., Reinhardt, R., Heute vor Gott reden, Grünewald 1977.

Hoekstra, T., Gereformeerde Homiletiek. Wageningen s.j.

Jenson, R.W., "The preacher, the text and certain dogmas", Biblical Theology Bulletin 12/3(1982). 
Jonker, H., En tóch preken, Nijkerk 1973.

Kohis, E.W., (Hrsg), Evangelische Katechismen der Reformationszeit, Gütersloh 1971.

Läpple, A., Kleine Geschichte der Katechese, München 1981.

Lekkerkerker, A.F.N., "De leerdienst", Kerk en Eredienst Jrg VIII/3 (1952)

Lekkerkerker, A.F.N., Gesprekken over de Heidelberger, Wageningen 1964.

Luther, M., Grosser Katechismus. 1529, Berlin ${ }^{10} \mathrm{~s}$.j.

Luther, M., Kleiner Katechismus. 1529, Hannover, 1958.

Miskotte, K.H., Om het levende Woord, Den Haag 1948.

Polman, A.D.R., Woord en belijdenis. I, Franeker s.j.

Prins, J.M.G., Die Heidelbergse Kategismus as kategetiese /eerstof, Stellenbosch 1973.

Schönherr, A., u.ä., Bekenntnisse der Kirche als Ruf in der Zeit, Göttingen 1980.

Schüts, Probleme der Predigt, Göttingen 1981.

Seebass, A., Dass wir an /hm bleiben, dem treuen Heiland, Hermannsburg ${ }^{6} 1967$.

Seidel, H., Bieritz, K.H., Das lebendige Wort, Berlin 1982.

Sweazey, G.E., Preaching the Good News, New Jersey 1976.

Trimp, C., De actualiteit der prediking, Groningen 1971

Van't Veer, M.B., Catechese en catechetische stof bij Calvijn, Kampen 1942.

lierhonderd jaar Heidelbergse catechismus, Uitg. Het "Comité herdenking Heidelbergse

Catechismus", 1963.

Volten, H., Rondom het belijden der kerk, Kampen 1962.

Wiener, J. u.ä., Gemeindekatechese, Freiburg 1981.

Wielenga, B., Onze Catechismus /, Kampen s.j.

Wisse, G., Homiletiek, Kampen 1980. 